\title{
Explaining the Evolutionary Dynamics of an Insurgency: T. E. Lawrence and the Art of Tribal Warfare
}

\author{
JOBBÁGY Zoltán, ${ }^{1}$ BAKOS Csaba A. ${ }^{2}$
}

\begin{abstract}
Despite the advances made in social and industrial life hundreds of millions of people world-wide live in social groups that can be described as tribes. These groups translate into segments of societies that have little to do with political entities. Enemies with tribal identity are difficult to defeat, which is due to the inherent dynamics of primitive or tribal warfare that feature a strong similarity with biological evolution. In the case favourable conditions exist, these dynamics can accumulate into victory of the weaker and defeat of the stronger. In order to support this statement the authors use the Arab Revolt (1916-18) as an example, which is excellently explained in the "Seven Pillars of Wisdom" written by T. E. Lawrence.
\end{abstract} Keywords: evolution; tribal warfare; insurgency; Arab Revolt; T. E. Lawrence

In the article the authors first introduce the observed tendency that in asymmetric wars the weaker side has a greater chance to prevail. Then they detail certain, mostly wrong perceptions and assumptions regarding the nature of primitive or tribal warfare. This is followed by a short treatise on the obvious similarities between biological evolution and war in general.

After that the internal dynamics of the Arab Revolt as recorded by T. E. Lawrence in his epic volume "Seven Pillars of Wisdom" is introduced. Then one particular theory on biological evolution, the shifting balance theory, is introduced to display the similarities in terms of internal dynamics between biological evolution and primitive or tribal warfare. The article ends with a conclusion.

\section{Changing Prospects}

The expected peace period after the demise of the bipolar world order did not last very long. Regular soldiers soon found themselves involved in many little regional wars that very much differed from their ingrained perception of what a proper war should look like. These wars were not symmetric, not regular, and not of high intensity. They did not involve armed forces with standardized weapons, uniforms and procedures to defeat, but various ragtag bands, armed and equipped with what they could get in a globalized world. More than two decades after the end of the Cold War, aberration to war proper appears to be the new norm for waging war. [1] After years of constant involvement in missions world-wide it has also become clear that this breed of enemy is very difficult to defeat. They are very resilient and

1 Lieutenant Colonel, Ph.D., National University of Public Service, The Faculty of Military Sciences and Officer Training, Department of Joint Operations, Budapest, Hungary, E-mail: Jobbagy.Zoltan@uni-nke.hu

2 Major, National University of Public Service, Budapest, Hungary, The Faculty of Military Sciences and Officer Training, Department of Joint Operations, E-mail: Bakos.Csaba.Attila@uni-nke.hu 
able to turn initial weakness into eventual strengths. The war they wage appears primitive to regular soldiers and has very much in common with the tribal wars of sub-state societies of the past. Clausewitz, the great Prussian military theorist made clear that in war nothing is eternal and there could be little doubt that previous ways of fighting would always reappear. [2] [3]

A good century ago when regular soldiers met enemies waging primitive or tribal warfare the result was one-sided and often there was almost no need for elaborate tactics, as superiority in armament was mostly decisive in itself. Scholarly research states that imperialist expansion in the late nineteenth and early twentieth century was made possible because tribal resistance was crushed with speed and efficiency. The overwhelming success was attributed to asymmetry in the form of military capability. As a consequence, common thinking has long assumed that the difference in military technology, manifest in weapons systems employed is an important arbiter of war. [4] [5] [6: 86]

\section{Tough Enemies, Biased Perception}

The logical conclusion of the common thinking as mentioned above would be that should military capability imply victory in war, the weaker side almost never wins against a stronger power, especially when the gap is very large. Yet examples in history suggest otherwise as the weaker side also wins from time to time. The second half of the $20^{\text {th }}$ century showed that military and technological superiority are a highly unreliable guide to the outcome of asymmetric wars. In fact, the many wars that were waged after World War II brought home important lessons on the falsity of the conception of military power. It became clear that superiority in military capability does not guarantee victory and under certain circumstances it may be even counter-productive as a factor. [7: 216-218] [8] [9] Possible explanations among scholars for this tendency are varied. One assumes that because of the possible negative consequences the weaker side fights harder and displays a willingness to accept losses that would be intolerable for the stronger power. This disparity in interest is one plausible explanation for the weaker side's tenacity and staying power. Another scholar highlights the weaker side's stronger political will, the third regards the weaker side's superior strategy as decisive, whereas another approach underlines the importance of access to external assistance. [8: 102-123] [9: 175-200] [10]

The general and biased perception toward primitive or tribal warfare was laid down in the 1940s. Since then a general consensus among scholars arose that tribal wars do not involve many casualties as the total number of people killed in battle is usually small. Participation is not very risky; therefore these wars can be described as substandard and cowardly, waged half-heartedly at best. Tribal wars also suffer from a number of deficiencies such as poor mobilisation of manpower, complete reliance on voluntary participation, poor logistics and supply that make the protraction of campaigns impossible. There are no formalised units, there is no organised training, command and control is generally poor. There is a lack of discipline and as a result morale is flighty. In such wars no specialised weapons are used and there is a clear absence of fortifications. No professional warriors are involved and no signs of military specialisation can be found. Tactics are ineffective and there are no principles to be distilled. [11: 8-14] [12] Hence the enduring and very resilient picture of these wars as a relatively harmless sport and not war proper was created. It should not come as a surprise that in the 
many explanations for the reasons why tribes wage war anthropologists have listed sport and entertainment as important reasons. [13: 164-165] [14: 135-144]

A thorough understanding of primitive or tribal warfare is important not only from the academic, hence theoretical point-of-view. Despite the advances made in social and industrial life much of the world's population is located in nation-states without being really part of them. Hundreds of millions of people live in many ways as tribes of old and translate into segments of societies that have little do with political entities. [15] The consequence is that their wars resemble similarities with wars waged in the past. It is also important to note that throughout human history wars were mostly waged by social entities other than states, fought by social organizations other than armies with the involvement of combatants other than soldiers. These wars were mostly non-decisive, protracted engagements fought for limited objectives and by limited means. They were a permanent way of life and viewed as natural phenomenon. [3: 608] [16: 3] [17: 64] [18: 73] [19] [20] Unlike political wars regular soldiers are familiar with, these wars were necessary and brute mechanisms for the survival of the people involved in them and featured patterns and reasons thought to be extinct for long. [7: 15]

\section{Biological Evolution and War}

War, even primitive or tribal war, displays structural unpredictability that suggests definite limits to what can be known at any given point in time. War has a non-quantitative and non-predictive character, which makes it impossible for the empirical or hard sciences to offer suitable descriptions, explanations or models. Given war's structural unpredictability, its dynamic and constantly changing nature, it is assumed that biological evolution may offer better foundations for a theory of war than most quantitative sciences. [14: 135-144] [21: 49-55]

Detecting obvious similarities between biological evolution and war is not difficult. In his book titled Adaptive Coloration in Animals biologist Hugh Cott observed a striking similarity between the primeval struggle of the jungle and the refinements of civilized warfare. He regarded biological evolution as struggle for existence and described it as interspecific warfare. Cott also stated that both evolution and warfare have much the same story to tell. In evolution and warfare there are results of an armament race and an invention race, which have led to a complex state of preparedness. The methods employed in both are, according to him, mainly similar as shown by the evolution of speed, on land, in the air, and under water, by pursuer and pursued. Both can be characterized by the employment of stealth and surprise, of deception and ambush. There is a display of warning signals and of alluring baits, the elaboration of smoke-screens, traps, nets, parachutes, of electrocution and booby-traps. In both there is evidence for fossorial and nocturnal habits, the development of poison, and of deadly apparatus in the form of fangs, stings or arrows. Protection in both is afforded by armour-plating, spines and barbed wire. Chemicals are used both in evolution and warfare as practiced by certain insects and by creatures such as the skunk. [22: xi-xii]

The American military thinker John Boyd too, advocated that evolution by natural selection and the conduct of war are intimately related. Soldiers and biologists share similar problems as both try to find a function that matches the crude reality of life. Both evolution and war reflect conflict, survival, and conquest in a very similar and fundamental way. They feature processes that include trial-and-error mechanisms and oscillate on a continuum 
that cannot be broken into discrete points or steps in time. [13] [23: 59-80] [24: 229-235] [25: 32-33] [26: 217] [27: 11] T. E. Lawrence, the author of "Seven Pillars of Wisdom" and leader of the Arab Revolt in 1916-18 also found a biological element in warfare that was inexpressible with hard or quantitative sciences. This element was for him not subject to the laws of mathematics as it dealt with unknown variables, unfixed conditions, and organic things. Its focus was the individual without artificial aids, an intangible that drifts about like gas. This element, he stated, does not live on any material and does not offer any material to the killing. The biological element appeared for him messy and slow like eating soup with a knife. Lawrence regarded this element the breaking-point, which decided on life and death. The biological element was humanity in battle, the personal experience, and the very war with a line of variability running through all its aspects. Its components were sensitive and illogical, with always the possibility of accidents and flaws. The biological element was not expressible in troops or figures, but existed as intuitions. He reasoned that even if nine-tenths of warfare was certain and could be taught in books the irrational rest could be ensured only by instinct. Due to this biological element he stated that amateur control, experimental councils, ad-hoc divisions, and all sorts of whimsicality are inherent features of war. [28: 101]

\section{Dynamics of the Arab Revolt}

At the beginning of the Arab Revolt the tribal setup of the Arabs was not promising. Arab tribes were bellicose, but they normally went to war in order to gain honour and wealth. There were no principles for their hasty practice of warfare and tactics were empirical snatchings of the first means. The three noble spoils for which they usually waged war were arms, good riding-animals, and nice clothes. National union was always episodic and never deeper than a combined resistance to an intruder. The tribes were not familiar with the meaning of mass nor could they display corporate spirit or mutual confidence. They did not know military discipline in the sense of restricting and submerging individuality. Without formality of discipline there was no formal subordination and there was no distinction in terms of military ranks. Virtue of accomplishment was regarded more important as only the only person who could be a leader was the one who appeared better than the rest. The Arabs were volunteers, individuals, local men, relatives, but never soldiers. They fought in parties and not in stiff formations, their warfare was intentional and attack was always imminent. [28: 86, 124, 144, 150-151, 281, 504]

During the revolt the Arab contingents were continually shifting. Young men often served only for a few days, married men alternated between camp and wife, and sometimes whole clans became bored and just took a rest. Any of the Arabs could go home without risking a penalty as the only contract to serve was honour. Blood feuds were nominally healed, but members of one tribe were suspicious of each other and within a tribe no man trusted his neighbour. The distribution of the raiding parties was ad-hoc as due to their distrusts, and it was impossible to mix or combine tribes, and no tribe could be used in the territory of the other. This dissipation added fluidity to speed, reinforced the tribes' natural mobility, and always refilled their ranks with fresh men. Each new tribe involved maintained their pristine energy. Fresh forces were composed of local men who knew the qualities of their ground and fought best there. The result was utmost disorder in which the raiding parties achieved maximum irregularity and extreme articulation. Their circumstances were not similar twice and no sys- 
tem could fit them twice as the tribes never tried to maintain or improve any advantage. They always moved off and struck again somewhere else with the smallest force, in the quickest time, at the farthest place. Arab tribal warfare was like naval warfare featuring mobility, ubiquity, and independence of bases, independence of communications, lack of ground features, lack of fixed directions, and lack of fixed points. [28: 89, 329-330]

It turned out during the revolt that the assets of the tribesmen were movement, endurance, individual intelligence, knowledge of the country, and courage. Tactically the tribes represented a highly mobile, highly equipped army of the smallest size. Having five times the mobility of the Turks they needed only one-fifth of their number. Arab tribal warfare was simple and individual as every participating man was self-contained. Their efficiency came from the personal efficiency of the single man and the sum yielded by them at least equalled that of a compound system of the same strength. As T. E. Lawrence remarked, this sort of warfare was more intellectual than a bayonet charge and more exhausting than the obedient service in a regular army. The moral strain of isolated fighting made war very hard upon the individual, exacting special initiative, endurance, and enthusiasm. [28: 330] [29: 12-14, 19, 20]

During the revolt the Turks had to cope with unforeseen difficulties as the activity of the tribes behind their back continuously hampered them. Tribal raids caused daily losses of camels and men killed or wounded. Even those clans who fell away from the revolt did not become trustworthy. The Arabs' diversity threw the Turkish intelligence off the track as their strength depended upon whim. No spy was able to count them, as the Arabs themselves had no idea of their strength at any given place or moment. The Arabs also had the habit of never engaging the enemy. They never disclosed themselves until the moment of attack, which was directed not against the enemy's men, but against his materials. Over time the tribes made themselves superior in one branch that turned out to be decisive. They modified one maxim of warfare, being superior at the critical point and the moment of attack, and applied it to the railways. Their aim was to reduce the railway to working with the maximum loss and discomfort. They did only a little damage to the line to annoy the Turks without making them fear its final destruction. The tribes thus sought the weakest link and hit only that, till time made it fall. [28: 122, 183-184, 215-216, 329, 467-469]

T. E. Lawrence regarded the tribal war of the Arabs a sort of national strike, a nature of peace in which they lived by their raggedness and, in the end, won by uncertainty. The revolt was not war of contact and there were no pitched battles either, since the enemy was contained by the threat of a vast and unknown desert. The strategic strength of the tribes came from time as the war was going neither well nor very ill, and it always seemed as though there might be time for another try next year. Their victory was not so much based on their ability to do things perfectly, as the Arabs had a preference for botching things somehow, rather than letting things go altogether by default. The value of the tribes came from their quality for this special sort of warfare in which quantity, in terms of numbers, was not decisive. The few active rebels who were probably never more than two percent of the total population had qualities such as speed, endurance, ubiquity and independence of supply. They had the technical equipment to destroy or at least paralyse the enemy's communications. [28: 132, 184-186, 215, 379, 538] 


\section{Dynamics of Biological Evolution}

British military theorist Liddell Hart once wrote that "instead of fusing individuals into a mass through the suppression of their individuality and the contraction of their thought, the lead (...) only has effect, lightning effect, in proportion to the elevation of individuality and the expansion of thought. For collective action it suffices if the mass can be managed; collective growth is only possible through the freedom and enlargement of individual minds. It is not the man, still less the mass, that count; but the many.” [30: 356] He also stated that in war "bad means deform the end, or deflect the course thither"; therefore the only thing left possible is to acknowledge that "if we take care of the means the end will take care of itself.” [30: 357]

His observation on war is in full accordance with T. E. Lawrence's description of the nature of Arab tribal warfare, which he regarded as simple and individual. Every participating man was self-contained. The personal efficiency of the single man did matter, which at least equalled that of a compound system of the same strength. In a similar fashion biologist Sewell Wright regarded evolution to be driven by efficiency, hence the interaction of single genes. He wanted to understand the properties of gene mutation and to better understand the underlying dynamics of the process he introduced the shifting balance theory, also known as the theory of the fitness landscape. Fitness described for him the relative success of a species in relation to others in the environment. He stated that biological evolution happens in a constantly changing environment in which a species' suitability to the circumstances can alter in subtle and dramatic ways. [31] [32] Wright's theory appears to be a powerful aid to conceptualise any complex phenomenon, including war. As a graphic representation, a short and non-mathematical approach it resembles a certain similarity with a topographical map. Although he emphasised that references to geography are of secondary importance, the result was a map containing multiple peaks surrounded by circular contours defined by two axes representing the dimensions along which possible combinations could be arranged. Every combination had a certain value and by connecting the points of equal value contours of peaks and valleys arose. [32: 67-68] [33] [34]

Wright assumed that evolutionary selection could carry the species to the top of the nearest peak, but could not cross valleys that separate the current peak from other, probably higher ones. However, should the species be able to cross valleys then it is not under the exclusive control of natural selection, but of certain trial-and-error mechanisms. An indefinitely large species, that lives under constant environmental conditions and is exposed only to natural selection, can reach equilibrium by occupying a certain peak. The population either grows through an increase in mutation rate or a decrease in mass selection, or it decreases through the opposite process. In both cases evolutionary selection alone does not seem to be sufficiently strong to push the species towards another and possibly higher peak. [33: 360-362] [34: 117] Wright assumed that the environment is never static, but changes continuously. The landscape constantly deforms by depressing high places and elevating low ones. According to him, if a species is not extremely specialised and occupies a wide field on the landscape, by moving constantly it could find higher general regions. Such a trial-and-error mechanism can shuffle the species about by means of change without advance in adaptation. As a solution he proposed a large species to be subdivided into many local races that shift continually in a non-adaptive 
fashion on the landscape. Although this exploratory process could result in a decrease of fitness as an immediate effect, this way it would become possible that at least one local race finds a higher peak and pulls the entire species towards this better position. Wright emphasised that a subdivision of a species into local races provides the most effective adaptation mechanism for trial and error in the field of gene combinations. [31: 363] Thus evolutionary adaptation involves differentiation in which the principal mechanism is essentially non-adaptive. Wright regarded evolution as a dynamic process in which adaptation comes as a result of a careful balance between natural selection and random genetic drift. In this process each has a varying contribution to the survival and extinction of species over time and space. He proved that adaptation and chance events play an important role in biological evolution. [32: 73-75]

\section{Conclusion}

Wright's theory of the shifting balance allows for conceptualising the Arab Revolt as a complex phenomenon that involves adaptation and trial-and-error. According to his theory the Arabs and the Turks can be regarded as two species each trying to increase its own fitness at the expense of the other. The war between them can thus be visualised as a landscape with a constantly changing surface that contains multiple peaks. The height of the peaks corresponds to the value of the effects the Arabs and the Turks achieved during the war.

As indicated by the shifting balance theory, due to their tribal structure, the Arabs were more fit to survive in this constantly changing environment. Over time they won the war against the Turks, with the result that the political map of the Arab Peninsula changed in a subtle and dramatic way. The dynamics of their tribal warfare made it possible for them both to occupy high peaks in the landscape and to cross valleys that separated those peaks. Arab tribal warfare was able to exploit the trial-and-error mechanisms to a higher degree, which better corresponded to inherent dynamics of the constantly changing environment. Their loose tribal setup, their lack of indoctrination in terms of processes and procedures resulted in lesser specialisation. In other words, they were able to occupy a wider field in the landscape and could move about constantly thus finding higher general regions and occupy higher peaks. They were able to shift continually in a non-adaptive fashion on the landscape and this way they found by accident that damaging railways was unbearable for the Turks in the long term. This chance discovery of some local Arabs and T. E. Lawrence spread through their ranks and became a general practice until the end of the war.

Tribal warfare is a form of war and as such it is a dynamic process, which is scarcely in equilibrium. In the end the subdivision of the Arabs into local entities, the shifting balance of the various tribes proved to be more effective than the Turks centralised structure and strict military hierarchy. Thus victory in such wars comes from a careful balance between selection and random events, which continuously shift back and forth. In the end it turned out those horizontal structures, decentralised command and bottom-up processes of the tribes proved to be the more effective. Adaptation in war is certainly important, but as the Arab Revolt shows adaptation alone does not help anybody to win any sort of war. Trial-and-error is just as much an important factor in waging war and must be considered with equal weight. The success of the Arab Revolt stands for a clear limitation on the assumption that any careful process of optimising, which is often described by the word adaptation, alone will yield an advantage and later victory in war as it has been observable in recent wars. 
JOBBÁGY Zoltán, BAKOS Csaba A.: Explaining the Evolutionary Dynamics of an Insurgency...

\section{References}

[1] MACKENZIE, R.: The Afghan War. Air Force Magazine, 09 1988, 150-153.

[2] GRANT, M. M.: The COiNventional Wisdom. Small Wars Journal, 082012.

[3] CLAUSEWITZ, C. von: On War. Everyman's Library, 1993.

[4] HENEKER, W. S. G.: Bush Warfare, The Early Writings of General Sir William C.G. Heneker, KCB KCMG DSO. Ottawa: Department of National Defense, 2009.

[5] War Office: British Army Field Service Regulation. London: Harrison and Sons, 1909.

[6] ELLIS, J.: The Social History of the Machine Gun. New York City: Pantheon Books, 1975. In. TOFFLER, A.: The Third Wave. New York City: Bantam Books, 1981.

[7] LeBLANC, S. A., REGISTER, K. E.: Constant Battles, The Myth of the Peaceful, Noble Savage. New York City: St. Martin’s Press, 2003.

[8] ARREGUÍN-TOFT, I.: How the Weak Win Wars, A Theory of Asymmetric Conflict. International Security, Summer 2001, 93-128. https://doi.org/10.1162/016228801753212868

[9] MACK, A. J. R.: Why Big Nations Lose Small Wars: The Politics of Asymmetric Conflict. World Politics, 01 1975, 175-185.

[10] RECORD, J.: Why the Strong Lose. Parameters, Winter 2005, 16-31.

[11] KEELEY, L. L.: War before Civilisation, The Myth of the Peaceful Savage. Oxford: Oxford University Press, 1996.

[12] SCHNEIDER, J.: Primitive Warfare: A Methodological Note. In. BRAMSON, L., GOETHALS, G. W. (Eds.), War, Studies from Psychology, Sociology, Anthropology. New York City: Basic Books, 1968, 283-291.

[13] HARRIS, M., JOHNSON, O.: Cultural Anthropology. New York City: Pearson Education, 2003.

[14] GARDNER, R., HEIDER, K. G.: Gardens of War - Life and Death in the New Guinea Stone Age. New York City: Random House, 1968.

[15] Tribes still matter, how global leaders tap into diaspora networks. The Economist, 2001 2011. www.economist.com/node/17928961 (downloaded: 1906 2014)

[16] HAMMES, T. X.: The Sling and the Stone, On War in the $21^{\text {st }}$ Century. Minneapolis: Zenith Press, 2004.

[17] TOFFLER, A., TOFFLER, H.: War and Anti-War, Survival at the Dawn of the $21^{\text {st }}$ Century. New York City: Little, Brown and Company, 1993.

[18] CREVELD, M. van: The Transformation of War: The Most Radical Reinterpretation of Armed Conflict since Clausewitz. New York City: The Free Press, 1991.

[19] UJHÁZY L.: Allied Joint Force Command Headquarters Brunssum's Deployed Joint Forces Headquarters Training. Academic and Applied Research in Military Science, 3 (2008), 445-451.

[20] WEGMAN, Y.: Israel's Security Doctrine and the Trap of “Limited Conflict”. Military Technology, 03 2005, 86-89.

[21] WATTS, B. D.: Clausewitzian Friction and Future War. Washington, D.C.: National Defence University, 2004.

[22] COTT, H. B.: Adaptive Coloration in Animals. London: Methuen \& Co. Ltd., 1957. (Quotation on xi).

[23] GLEICK, J.: Chaos, Making a New Science. New York City: Viking Penguin Inc., 1987. 
JOBBÁGY Zoltán, BAKOS Csaba A.: Explaining the Evolutionary Dynamics of an Insurgency...

[24] WILLIAMS, G. P.: Chaos Theory Tamed. Abingdon: Taylor \& Francis, 1997.

[25] BYRNE, D. S.: Complexity Theory and the Social Sciences. An Introduction. London: Routledge, 1998. https://doi.org/10.4324/9780203003916

[26] ALCHIAN, A. A.: Uncertainty, Evolution, and Economic Theory. The Journal of Political Economy, 061950.

[27] BOYD, J.: Patterns of Conflict, 12 1986. www.d-n-i.net/boyd/pdf/poc.pdf (downloaded: 1905 2014)

[28] LAWRENCE, T. E.: Seven Pillars of Wisdom. Wordsworth Classic of World Literature, 1997.

[29] LAWRENCE, T. E.: Evolution of a Revolt. CSI Reprint, 1968.

[30] Quotation in LIDDELL HART, B. H.: Through the Fog of War. London: Faber and Faber Ltd., 1938.

[31] WRIGHT, S.: The Roles of Mutation, Inbreeding, Crossbreeding and Selection in Evolution. Proceedings of the Sixth International Congress of Genetics, 1932, 356-366.

[32] JOSHI, A.: The Shifting Balance Theory of Evolution. Resonance, 12 1999, 66-75.

[33] WRIGHT, S.: Surfaces of Selective Value Revisited. Notes and Comments. The American Naturalist, 01 1988, 115-116. https://doi.org/10.1086/284777

[34] WRIGHT, S.: "Surfaces" of Selective Value. Proceedings of the National Academy of Sciences USA, 1967, 165-172. https://doi.org/10.1073/pnas.58.1.165 